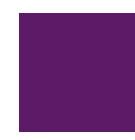

\title{
Lod z
}

Economics

Working

Papers

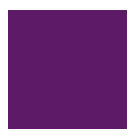

\section{THE HETEROGENEITY OF CONVERGENCE IN TRANSITION COUNTRIES}

Mateusz Pipień

Sylwia Roszkowska 


\title{
The Heterogeneity of Convergence in Transition Countries ${ }^{1}$
}

\author{
Mateusz Pipień2 ${ }^{2}$ Sylwia Roszkowska ${ }^{3}$
}

\begin{abstract}
:
For two groups of post-communist countries (CEE and CIS) we estimated the parameters of convergence equations on the basis of annual data. We depart from standard econometric theory, which involves panel regression techniques. We test cross-country heterogeneity of parameters within a system of Seemingly Unrelated Regression Equations (SURE). We show empirical evidence in favour of the variability of parameters describing the convergence effect and productivity growth rates across countries. Our approach seems a convincing alternative to the panel regression approach where random effects can be estimated, imposing an assumption about the constancy of structural parameters within the group of countries under analysis.

We discuss the role of the global financial crisis in the heterogeneity of convergence processes and productivity at the country level. The aforementioned SURE model was estimated based on two datasets, one containing observations prior to the crisis and the second containing the whole sample.
\end{abstract}

Keywords: convergence; labour productivity; economic growth; SURE

\footnotetext{
${ }^{1}$ This research was financed by the National Science Centre, Poland (decision DEC-2016/21/B/HS4/01565)

${ }^{2}$ Department of Econometrics and Operations Research, Cracow University of Economics

${ }^{3}$ Department of Macroeconomics, Faculty of Economics and Sociology, University of Lodz
} 


\section{Introduction}

Economic convergence is a catching-up process observed in the case of less developed economies which tend to the level of economic development observed in more developed ones. The empirical evidence supporting the existence of the convergence effect is analysed using the concepts of $\beta$ convergence and $\sigma$-convergence, introduced by Barro and Sala-i-Martin $(1991,1992)$.

The term $\beta$-convergence refers to conditional convergence and implies a negative relationship between the initial level of development (GDP per capita or labour productivity) and growth. The effect of conditional convergence results in the assumption that each economy converges to its own steady-state value, and the GDP growth rate depends on the distance between the existing and steady-state level of output. Convergence in that sense is conditional, as the steady-state value of output per worker depends on a variety of factors that may differ across countries; see Barro (1997)

The issue of conditional convergence has been studied by many authors since the nineties. The resulting estimated value of convergence rate reached approximately $2 \%$ annually; see Barro, Sala-iMartin, (1992), (1995), and Mankiw et al. (1992). Over the past two decades, this seminal result that the convergence rate should be close to $2 \%$ has become the subject of discussion. Many studies show that the convergence pace depends on the econometrics strategy applied in the analyses. In particular, Abreu et al. (2005), Arbia et al. (2008), and Dobson et al. (2006) compare the various results obtained based on different methods, and they present a review on the convergence literature focusing on $\beta$ convergence in a cross-country or panel data setting. They show that the convergence parameter may vary substantially with respect to the sample choice and econometric model.

Early studies conducted by Barro and Sala-i-Martin (1995) shown that the results greatly depend on the choice of the analysed group of countries. This may indicate the existence of the heterogeneity of convergence phenomena across countries. Since panel data techniques are commonly used in estimation, researchers often decide to divide panels into more homogenous a priori subgroups, like EU15, EMU, CEE, SEE, CIS, the Visegrad group, Baltic States and others. Borsi and Metiu (2015) investigate economic convergence in real income per capita between 27 EU countries in 1970-2010 using a non-linear latent factor framework. Their results suggest no overall real income per capita convergence in the EU, but subgroups that converge to different steady states are identified using an iterative testing procedure. The empirical evidence suggests a clear separation between the new and old EU member states, suggesting that, even though CEE has exhibited higher real income growth than the EU average over the last 40 years, catching up was not sufficient in order to eliminate crosscountry differences. They also find a South-East vs. North-West division of European countries. The existence of convergence clubs and heterogeneity across countries have been confirmed in analyses by Fritsche and Kuzin (2011). They used data from the EU15 countries in the period 1960-2006 and the non-linear time varying coefficients factor model proposed by Philips and Sul (2007) and they established regional clusters in income per capita, CPI, GDP deflator, unit labour costs and total factor 
productivity. Some of the analysed variables (e.g. income per capita) indicate the existence of three convergence clubs without strong regional linkages. A rather different approach was used by Özgüzer \& Oğuş-Binatlı (2016). They checked conditional convergence within the EU in 1995-2010. Apart from other traditional determinants of economic growth, the impact of economic complexity, measured by the indicator developed by Hidalgo and Hausmann (2009), was analysed. The estimated values of the convergence rate may differ within the Union. Additionally, a strong association between economic complexity and growth during the time span from 1995 to 2010 was supported. As regards complexity, Hidalgo and Hausmann (2009) identified a threshold that allows a particular economy to grow faster. In the case of the complexity index exceeding the threshold, the convergence occurs two times faster.

The heterogeneity of income convergence in the case of European countries was also confirmed by Gligorić (2014). His analysis using GDP per capita data from 1995-2013 utilised the pair-wise approach; see Pesaran (2007). The method identifies four cases: long-run convergence, catching-up, lagging-behind, and divergence. The catching-up case prevails, while no significant evidence was found for the existence of the long-run convergence in the case of the whole sample. In addition, the catching-up case prevailed in Europe before the crisis. Two convergence clubs were distinguished within the group of transition countries: Baltic (Estonia, Latvia and Lithuania) and Visegrad +3 (Slovakia, Poland, Czech Republic, and Hungary along with Croatia, Bulgaria, and Slovenia). The third club, called the Advanced countries, contained Italy, France, Germany, Portugal, Luxembourg, Sweden, Belgium, Norway, Denmark, Finland, the UK, Spain and Austria. After the crisis, the advanced club was split into two subgroups: PIS (Portugal, Italy, and Spain) and others.

Another important issue that is important when analysing convergence is the assessment of the impact of the global financial crisis on the pace of catching up. Using GDP per capita for 11 CEE countries that accessed the EU (EU11) and 15 countries of Western Europe (EU15) in 1993 and 2015, Matkowski et al. (2016) report more rapid growth of the CEE economies compared with the average growth in the EU15 over the period 1993-2015. Consequently, Matkowski et al. (2016) found empirical evidence in favour of the hypothesis that the economic crisis resulted in a deceleration of the convergence process in most CEE countries in 2007-2015. Forgó and Jevčák (2015) found that the majority of CEE countries achieved significant real convergence with euro area countries between 2004 and 2014. They also identified a slowdown in the catching-up pace after the crisis, which stopped the earlier investment boom and rapid growth. Investment as the most important determinant in the convergence process in CEE and SEE countries was indicated by Colak (2015). In this work, on the basis of a panel of 33 countries covering the period from 1993 to 2012, a strong tendency for catching-up in the analysed group was confirmed. Additionally, many recent studies indicate a change in the convergence pace after the last crisis; see Kaitila (2014), Halmai and Vásáry (2012), Marelli and Signorelli (2015), Greta and Lewandowski (2015). 
The strength of real convergence processes is usually estimated using growth regressions and panel data techniques. Usually, researchers make an inference about the existence of beta convergence with the use of fixed effects (FE), random effects (RE) and OLS techniques. Some authors address the endogeneity problem and apply GMM estimators; see Law et al. (2013), Young et al. (2015), and Kacprzyk (2016). Another group of authors discuss the problem of the existence of stochastic trends and test the dynamics within an analysed time series; see Kim et al. (2002) or Próchniak and Witkowski (2016). Hence, panel regression with fixed effects seems to be a point of departure for many empirical analyses involving much more complex frameworks. However, it is hard to find analyses that treat the effect of cross-country heterogeneity of convergence seriously. In this paper, we address this issue by relaxing the assumption of the constancy of structural parameters across countries. This leads us to apply the system of Seemingly Unrelated Regression Equations (SURE). We show empirical evidence in favour of the variability of parameters describing the convergence effect and productivity growth rates across countries. Our approach seems a convincing alternative to the panel regression approach where random effects can be estimated, imposing an assumption about the constancy of structural parameters within the group of countries under analysis.

In the empirical part of the paper, we estimate the parameters of convergence equations on the basis of annual data, covering the period from 1995 till 2015, for two groups of post-communist countries (CEE and CIS). We show empirical evidence in favour of the variability of parameters describing the convergence effect and productivity growth rates across countries.. We also discuss the role of the global financial crisis in the heterogeneity of convergence processes and productivity at the country level. The aforementioned SURE model was estimated based on two datasets; the first contains observations prior to the crisis (from 1995 to 2007) and the second contains the whole sample.

\section{An econometric model for convergence analysis}

Convergence analysis can be performed according to the neoclassical growth model, presented by Barro and Sala-i-Martin (1995). Within this dynamic framework, the parameter describing the speed of convergence, denoted by $\beta^{*}$, can be found using the following equation:

$$
(1 / T) \log \left(y_{j T} / y_{j 01}\right)=a-\left(\left(1-e^{-\beta^{*}}\right) / T\right) y_{j 0},
$$

where $a$ is an intercept and $T$ is the length of period. The steady-state level of output per capita $(y)$ or per worker depends on the choices of the private sector (the saving rates, labour supply and fertility rates); government sector choices (government spending, tax rates, the law and property rights, political freedom); external conditions (the terms of trade, geographical position etc.); see Barro (1997).

As a point of departure, we refer to the standard regression form of the convergence equation for a particular country: 


$$
\Delta \log \left(y_{t}\right)=\alpha_{0}+\sum_{m} \alpha_{m} x_{m t}+\beta \ln \left(y_{t-1}\right)+\varepsilon_{t}, t=1, \ldots, T
$$

where: $y_{t}$ denotes labour productivity (GDP per employed) in year $t$ (in PPP); $x$ 's are sets of additional explanatory variables determining productivity in an equilibrium. Parameter $\beta$ describes the speed of convergence and, according to this theory, it is expected to be negative. If $T$ in (1) is small enough then $\beta$ in equation (2) is similar to convergence parameter $\beta^{*}$. The set of explanatory variables in (2) can be determined empirically. In particular, Sala-i-Martin (1997), in his research on the empirical importance of factors determining the per capita output growth rates among countries all over the world, reports the following factors: primary schooling, investment price, fraction of tropical area, population density, government consumption share, malaria prevalence, life expectancy, colonialism dummies, openness, fraction of GDP in mining, ethno-linguistic fraction, religion, and geographical dummies. As some of these variables are not relevant to the analyses provided in this paper, we take into account the most important of them for the catching-up process in the CEE and former Soviet Union countries.

The vector of explanatory variables consists of investment rates, the government consumption to GDP rate, the inflation rate, and trend as a proxy for institutional or technological changes. For a particular country, equation (2) has the following form; see also Rogut and Roszkowska (2006):

$$
\Delta \log \left(y_{t}\right)=\alpha_{0}+\alpha_{1}\left(G_{t} / Y_{t}\right)+\alpha_{2} \pi_{t}+\alpha_{3} \pi_{t}^{2}+\alpha_{4} i_{t}+\alpha_{5} t+\beta \ln \left(y_{t-1}\right)+\varepsilon_{t}, t=1, \ldots, T,
$$

where $y_{t}$ denotes GDP in the country at year $t, G_{t}$ denotes government consumption expenditure in country at year $t, i_{t}$ is the investment rate (gross fixed capital formation in relation to GDP), $\pi_{t}$ is the inflation rate (percentage change of consumer prices over previous year), and $t$ is the time trend component. The most important interpretable parameter in (3) is the rate of convergence $\beta$, however, some additional information about the long-term growth rate of labour productivity can be determined. Providing an assumption about the constancy of the impact of steady-state variables on growth over time, the long-term GDP per employee growth rate, denoted by $g$, can be approximated as follows:

$$
g=\lim _{t \rightarrow \infty}\left[\Delta \log \left(y_{t}\right)\right]=\frac{\alpha_{5}}{\beta}
$$

In this paper, we perform cross-sectional analysis on the basis of the system of regression equations as an alternative for the very popular strategy utilising the panel regression approach. Suppose we analyse $n$ countries, and for $j$-th country $(j=1, \ldots, n)$ the convergence regression (3) is considered:

$$
\Delta \log \left(y_{t j}\right)=\alpha_{0 j}+\alpha_{1 j}\left(G_{t j} / Y_{t j}\right)+\alpha_{2 j} \pi_{t j}+\alpha_{3 j} \pi_{t j}^{2}+\alpha_{4 j} i_{t j}+\alpha_{5 j} t+\beta_{j} \ln \left(y_{t-1 j}\right)+\varepsilon_{t j}, t=1, \ldots, T, j=1, \ldots n
$$

The assumption that for each $j$, the Gaussian error terms $\varepsilon_{t j}$ in (5) are uncorrelated makes the system of equations independent. This case, denoted by $M_{0}$, formally refers to the empirical strategy of estimating convergence parameters separately within a particular $j$-th regression. However, in general, 
error terms $\varepsilon_{t j}$ may exhibit cross correlation, and the system (5) can be treated as a SURE model. We define this case as $M_{1}$. Nonzero contemporaneous correlations of error terms in (5) define a more ample stochastic structure particularly suitable for testing formally $M_{0}$ as a special case. The standard interpretation of nonzero contemporaneous correlations is also used as indicators describing linkages in the variability of related parameters across countries.

$\varepsilon_{t}=\left(\varepsilon_{t 1}, \ldots, \varepsilon_{t n}\right)$ denotes the row vector of error terms at time $t$ with the covariance matrix $\Sigma$. In the case of model $M_{1}$, the $\Sigma$ matrix is symmetric and positive definite with $n(n+1) / 2$ free elements $\sigma_{i j}^{2}$, $i=1, \ldots, n$ and $j=1, \ldots, n$. The standard notation gives the variance of the error terms in the $j$-th country as $\sigma_{i i}^{2}>0$ and covariance between error terms in the $j$-th and $i$-th country denoted by $\sigma_{i j}^{2}$. The system of equations (5) can be formulated in the following standard regression form:

$$
y^{(j)}=x^{(j)} \alpha^{(j)}+\varepsilon^{(j)}, j=1, \ldots, n
$$

Where $\quad y_{[T \times]]}^{(j)}=\left(y_{1 j}, \ldots, y_{T j}\right)^{\prime}, \quad X_{[T \times 1]}^{(j)}=\left(x_{1 j}{ }^{\prime}, \ldots, x_{T j}{ }^{\prime}\right)^{\prime}, \quad$ with $\quad x_{t j}=\left(1, G_{t j} / Y_{t j}, \pi_{t j}, \pi_{t j}^{2}, i_{t j}, t, y_{t-1 j}\right)$, $\varepsilon^{(j)}=\left(\varepsilon_{1 j}, \ldots, \varepsilon_{T_{j}}\right)^{\prime}$ and $\alpha^{(j)}=\left(\alpha_{0 j}, \alpha_{1 j}, \alpha_{2 j}, \alpha_{3 j}, \alpha_{4 j}, \alpha_{5 j}, \beta_{j}\right)^{\prime}$. In the next step, we stack the observations expressing the system of regression equations in the closed form:

$$
Y=X \alpha+\varepsilon
$$

Where $Y_{[n T \times 1]}=\left(y^{(1)}, \ldots, y^{(n)}\right)^{\prime},, \varepsilon_{[n T \times 1]}=\left(\varepsilon^{(1)}, \ldots, \varepsilon^{(n) '}\right)^{\prime}, \alpha_{[n 7 \times 1]}=\left(\alpha^{(1)}, \ldots, \alpha^{(n) \prime}\right)^{\prime}$ and:

$$
X_{[n T \times n]]}=\left(\begin{array}{cccc}
X^{(1)} & 0_{[T \times 7]} & \cdots & 0_{[T \times 7]} \\
0_{[T \times 7]} & X^{(2)} & \ddots & \vdots \\
\vdots & \ddots & \ddots & 0_{[T \times 7]} \\
0_{[T \times 7]} & \cdots & 0_{[T \times 7]} & X^{(n)}
\end{array}\right)_{[n T \times n 7]}
$$

A simple calculation yields the form of the covariance matrix for the error term $\varepsilon$ in (6):

$$
V(\varepsilon)=\Sigma \otimes I_{n}
$$

where $\otimes$ denotes the Kronecker product. The form of the covariance matrix of $\varepsilon$ makes system (6) a generalised linear regression. Based on $\Sigma$, the Aitken Generalised Least Squares estimator of all parameters in the system can be expressed in the following form:

$$
\hat{\alpha}_{G L S}=\left(X^{\prime}\left(\Sigma \otimes I_{n}\right)^{-1} X\right)^{-1} X^{\prime}\left(\Sigma \otimes I_{n}\right)^{-1} y,
$$

with the covariance matrix of the estimator given as follows:

$$
V(\hat{\alpha})=\left(X^{\prime}\left(\Sigma \otimes I_{n}\right)^{-1} X\right)^{-1} \text {. }
$$

In case $M_{0}$, where $\Sigma=\operatorname{diag}\left(\sigma_{11}^{2}, \ldots, \sigma_{n n}^{2}\right)$ we have the equivalence of Aitken's GLS to the application of the $O L S$ estimator for each equation separately:

$$
\alpha_{O L S}=\left(X^{\prime} X\right)^{-1} X^{\prime} y
$$


In a general case, $M_{1}$, we have to estimate covariance matrix $\Sigma$. In the empirical part of the paper, we apply Zellner's (1962) method, and estimate the elements of matrix $\Sigma$ on the basis of the OLS residuals, denoted by $\hat{\varepsilon}_{[n T x \mid]}=\left(\hat{\varepsilon}^{(1)}, \ldots, \hat{\varepsilon}^{(n)}\right)^{\prime}$ '. The Estimated $G L S$, proposed by Zellner (1962), takes the form:

$$
\hat{\alpha}_{E G L S}=\left(X^{\prime}\left(S \otimes I_{n}\right)^{-1} X\right)^{-1} X^{\prime}\left(S \otimes I_{n}\right)^{-1} y,
$$

with the approximated small sample covariance matrix of the estimator:

$$
\hat{V}\left(\hat{\alpha}_{E G L S}\right)=\left(X^{\prime}\left(S \otimes I_{n}\right)^{-1} X\right)^{-1},
$$

where

$$
S=\frac{1}{T}\left(\hat{\varepsilon}^{(1)}, \ldots, \hat{\varepsilon}^{(n)}\right)^{\prime}\left(\hat{\varepsilon}^{(1)}, \ldots, \hat{\varepsilon}^{(n)}\right) .
$$

The empirical importance of the system of regressions is supported when matrix $\mathrm{S}$ indicates that $\Sigma$ is not diagonal. It is clearly implied by possible cross correlations of error terms. The difference between an estimation with the use of $\hat{\alpha}_{E G L S}$ and $\hat{\alpha}_{O L S}$ also concerns the form of the covariance matrices. Since $\hat{\alpha}_{O L S}$ results from the assumption that matrix $\Sigma$ is diagonal, the small sample approximation of the covariance matrix of the estimator $\hat{\alpha}_{O L S}$ is of a similar form as in the case of $\hat{\alpha}_{E G L S}$, but the diagonal matrix $S_{\text {diag }}=\operatorname{diag}\left\{s_{11}^{2}, \ldots, s_{n n}^{2}\right\}$ is applied as an estimator of $\Sigma=\operatorname{diag}\left(\sigma_{11}^{2}, \ldots, \sigma_{n n}^{2}\right)$ :

$$
\hat{V}\left(\hat{\alpha}_{\text {OLS }}\right)=\left(X^{\prime}\left(S_{\text {diag }} \otimes I_{n}\right)^{-1} X\right)^{-1},
$$

with $s_{j j}^{2}=\frac{1}{T} \hat{\varepsilon}^{(j) \prime} \hat{\varepsilon}^{(j)} j=1, \ldots, n$.

In the empirical part of the paper, we test the statistical significance of the differences between parameters describing the speed of convergence, namely $\beta_{j}, j=1, \ldots, n$ across countries in system (5). We will perform it according to the standard testing procedure that involves estimating a linear combination of structural parameters. Suppose we are interested in a linear combination of structural parameters in (5) of the form $\gamma=c_{[n 7 x 1]} \cdot \alpha_{[n 7 \times 1]}=\left(c^{(1)}, \ldots, c^{(n) \prime}\right) \cdot\left(\alpha^{(1)}, \ldots, \alpha^{(n)} \prime\right) '$. The vector $c_{[n 7 \times 1]}$ contains the coefficients of a particular linear combination and is known. We define the EGLS and $O L S$ estimator of the function of interest $\gamma$ as follows:

$$
\hat{\gamma}_{O L S}=c \cdot \hat{\alpha}_{O L S}
$$

and

$$
\hat{\gamma}_{E G L S}=c \cdot \hat{\alpha}_{E G L S} .
$$

The small sample approximation of the variance of estimators is given as follows:

$$
\hat{V}\left(\hat{\gamma}_{O L S}\right)=c \cdot \hat{V}\left(\hat{\alpha}_{O L S}\right) \cdot c^{\prime}
$$

and for EGLS:

$$
\hat{V}\left(\hat{\gamma}_{E G L S}\right)=c \cdot \hat{V}\left(\hat{\alpha}_{E G L S}\right) \cdot c^{\prime}
$$


The aforementioned procedure can be applied to system (5) in testing country heterogeneity of structural parameters. Suppose we are interested in testing whether the difference between the convergence parameter in the $i$-th country is significantly different to the convergence parameter in the $j$-th country. More formally, we are interested in testing the following hypothesis framework:

$$
\begin{aligned}
& H_{0}: \beta_{i}-\beta_{j}=0 \\
& H_{1}: \beta_{i}-\beta_{j} \neq 0 .
\end{aligned}
$$

This can be conducted on the basis of the function $\gamma_{i j}=c_{[n 7 x 1]} \cdot \alpha_{[n 7 x 1]}$, with $c_{[n 7 x 1]}=\left(c^{(1)}, \ldots, c^{(n)}\right)$ such that $c^{(i)}=(0,0,0,0,0,0,1), c^{(j)}=(0,0,0,0,0,0,-1)$ and $c^{(m)}=(0,0,0,0,0,0,0)$ for $m \in\{1, \ldots, n\} \backslash\{i, j\}$. In this case, the $\gamma_{i j}$ simply means the difference between $\beta_{i}$ and $\beta_{j}$. Hence, testing country heterogeneity can be equivalently performed on the basis of the following testing hypothesis:

$$
\begin{aligned}
& H_{0}: \gamma_{i j}=0 \\
& H_{1}: \gamma_{i j} \neq 0 .
\end{aligned}
$$

The standard procedure of Student- $t$ test statistics can be applied, with the test statistics utilising the standard errors defined as the square roots of $\hat{V}\left(\hat{\gamma}_{i_{E G L S}}\right)$ in the case of the EGLS estimation procedure, or of $\hat{V}\left(\hat{\gamma}_{i j O L S}\right)$ in the case of the simpler method, based on the $O L S$ estimator. In the empirical part of the paper we perform those tests, making a comparison of the results in both cases of the form of matrix $\Sigma$ corresponding to $M_{0}$ and $M_{1}$.

We also performed an approximated inference about the long-term long-term growth rate of labour productivity according to (4). For a particular $j$-th country, the point estimates of $g_{j}=\frac{\alpha_{5 j}}{\beta_{j}}$ can be obtained either by the function of the OLS estimates, denoted by $\hat{g}_{\text {joLS }}$ or by the function of the EGLS estimates, denoted by $\hat{g}_{j E G L S}$. The small sample approximation of the variance of underlying estimators is given as follows:

$$
\hat{V}\left(\hat{g}_{j O L S}\right)=\frac{\partial g_{j}}{\partial \alpha} \cdot V\left(\hat{\alpha}_{O L S}\right) \cdot \frac{\partial g_{j}{ }^{\prime}}{\partial \alpha}
$$

and

$$
\hat{V}\left(\hat{g}_{j E G L S}\right)=\frac{\partial g_{j}}{\partial \alpha} \cdot \hat{V}\left(\hat{\alpha}_{E G L S}\right) \cdot \frac{\partial g_{j}}{\partial \alpha},
$$

with gradient vector $\frac{\partial g_{j}}{\partial \alpha}$ calculated at corresponding point estimates.

As with testing problem (7), one can verify the hypothesis that long-term growth rates of labour productivity vary across countries. More formally, we are interested in testing the following hypotheses: 


$$
\begin{aligned}
& H_{0}: g_{i}-g_{j}=0 \\
& H_{1}: g_{i}-g_{j} \neq 0 .
\end{aligned}
$$

for each $i, j=1, \ldots, n$ and $i \neq j$. The Student- $t$ type test statistics can be derived utilising point estimates and the variance of the following nonlinear function of parameters:

$$
\omega_{i j}=g_{i}-g_{j}=\frac{\alpha_{5 i}}{\beta_{i}}-\frac{\alpha_{5 j}}{\beta_{j}} .
$$

In this case, the point estimates in the OLS and EGLS frameworks, denoted by $\hat{\omega}_{i j O L S}$ and $\hat{\omega}_{i j E G L S}$ respectively, are given naturally:

$$
\hat{\omega}_{i j O L S}=\hat{g}_{i O L S}-\hat{g}_{j O L S}
$$

and

$$
\hat{\omega}_{i j E G L S}=\hat{g}_{i E G L S}-\hat{g}_{j E G L S},
$$

while the variance is obtained according to the formulae:

$$
\hat{V}\left(\hat{\omega}_{i j o L S}\right)=\frac{\partial \omega_{i j}}{\partial \alpha} \cdot V\left(\hat{\alpha}_{O L S}\right) \cdot \frac{\partial \omega_{i j}{ }^{\prime}}{\partial \alpha}
$$

and

$$
\hat{V}\left(\hat{\omega}_{i j E G L S}\right)=\frac{\partial \omega_{i j}}{\partial \alpha} \cdot \hat{V}\left(\hat{\alpha}_{E G L S}\right) \cdot \frac{\partial \omega_{i j}}{\partial \alpha}
$$

with gradient vector $\frac{\partial \omega_{i j}}{\partial \alpha}$ calculated at corresponding point estimates.

\section{Empirical analysis}

The analyses provided in the paper are based on a time series of cross-section data containing information about growth in 20 transition economies (see Figure 1). The dataset covers the period from 1992 to 2015. Our core variable is GDP per employed person, measured in constant prices and PPP. Our sample is divided into 2 separate groups: 8 CEE countries (the Czech Republic, Estonia, Hungary, Latvia, Lithuania, Poland, Slovakia, and Slovenia) and 12 CIS countries (Armenia, Azerbaijan, Belarus, Georgia, Kazakhstan, Kyrgyzstan, Moldova, the Russian Federation, Turkey, Turkmenistan, Ukraine, and Uzbekistan). Additionally, we study the subperiod 1992-2007 to reveal the pre-crisis patterns in convergence developments. We use data from the United Nations Database, United Nations Statistical Division, http://unstats.un.org/unsd/databases.htm.

\subsection{Results obtained for CEE countries}

Figure 2 presents the results of the inference about convergence parameters $\beta_{j}$. We present $95 \%$ confidence intervals and point estimates (black squares). We compare the estimates in the case of independent country regressions (model $M_{0}$, first column) and the SURE model ( $M_{1}$, second column). 
Figure 2 also presents results obtained based on the whole sample (second row) and the data covering the period prior to the crisis (first row).

The point estimates of $\beta_{j}$ obtained from $\hat{\alpha}_{O L S}\left(\operatorname{model} M_{0}\right)$ and $\hat{\alpha}_{E G L S}\left(\operatorname{model} M_{1}\right)$ are qualitatively the same in the analysed sample. We observe a substantial difference between the estimated speed of convergence and the nature of its heterogeneity across countries given both analysed datasets. Analysing the results obtained for the sample that ends in 2007, we report strong variability of convergence parameters, as the point estimates of $\beta_{j}$ vary across countries from a value close to -1.5 for Slovenia to a slightly positive value for Poland. Additionally, the spread of $95 \%$ confidence intervals varies across models, making inference about the heterogeneity of convergence parameters relatively weak in the case of model $M_{0}$ (OLS case) and much stronger in case of model $M_{1}$ (EGLS case). Estimation of convergence parameters according to the Zellner methods results in much more concentrated confidence intervals, especially in the cases of Estonia, Latvia, Lithuania and Slovenia. Consequently, as $95 \%$ confidence intervals of $\beta_{j}$ are located in separate regions of the domain, the hypothesis about the heterogeneity of convergence across the analysed countries is qualitatively supported for the shorter sample. Analysis for the whole sample yields a rather different picture. In this case (the second row in Figure 2), the point estimates of the convergence parameters are negative for all countries and not less than -0.5 , except for Slovenia which is characterised by a convergence pace almost two times faster. All remaining countries exhibit qualitatively the same convergence pace, with point estimates localised close to the value -0.25 . Also, the spread of $95 \%$ confidence intervals is substantially smaller than in case of the dataset until 2007. Once again, the Zellner estimates make the inference about the convergence parameters more precise, as the confidence intervals in the case of model $M_{1}$ are narrower than in the case of $M_{0}$. However, those intervals are located in the same region of the domain of the convergence parameters for all countries except Slovenia. This makes inference about the heterogeneity of convergence across the analysed countries vague.

For a pairwise comparison of the heterogeneity of convergence parameters across countries, we utilised testing problem (7) in both, $M_{0}$ and $M_{1}$ settings. In Table 1 and 2 we report the magnitude of the $p$-values of the test statistics, making a formal inference about the differences between convergence parameters. Table 1 shows the results obtained on the basis of the shorter sample, while Table 2 is related to the whole sample. The shorter sample (Table 1) provides decisive data support ( $p$ value less than 0.01) in favour of different convergence parameters in the case of at least 9 pairs of countries. This result is for model $M_{0}$. In the case of the unconstrained matrix of contemporaneous covariances (model $M_{1}$ ), the Zellner procedure of estimation strengthens the picture, resulting in 17 pairs of countries with decisive data support in favour of the hypothesis of different underlying convergence parameters. The null hypothesis in (7) is strongly supported in the case of 7 pairs of countries based on model $M_{1}$. These results remain unchanged for model $M_{0}$. In this case, two additional pairs of countries (LVA-EST and SVK-LVA) join the aforementioned group. 
A very different picture was obtained if the pairwise analysis was conducted on the whole dataset (Table 2). In this case, for both models we obtained at least strong data support (p-value less than 0.05 ) in favour of a difference between Slovenia (SVN) and the remaining group of countries. Additionally, based on model $M_{1}$, there is decisive data support for a difference in the convergence pace between Slovakia vs the Czech Republic and Latvia vs the Czech Republic. For all the remaining pairs of countries, a similar convergence pace is empirically supported.

In Figure 3, we report estimates of the long-term growth rate of labour productivity. Again, we analyse the estimates in the shorter sample (see the images in the first row) and the whole dataset (second row). We also compare results obtained in case of model $M_{0}$ (first column) and model $M_{1}$ (second column). According to (4), the approximate labour productivity growth rate can be described by a nonlinear function of parameters. Consequently, the inference about the underlying that rate is very diffuse. Based on the shorter sample, the point estimates differ across countries and the spread of $95 \%$ confidence intervals indicates quite a precise location of labour productivity for the majority of analysed countries. We report only two exceptions to this pattern. In those cases, the $95 \%$ confidence intervals depict information about uncertainty on a completely different and much greater scale than in the case of the other countries. The analyses conducted on the basis of the whole sample change the point estimates and also the spread of $95 \%$ confidence intervals quite strongly. For the Czech Republic and Poland, the point estimate of labour productivity is located slightly below the value of 0.02 . Also, the spread of $95 \%$ confidence intervals is much smaller than in case of the analyses based onthe shorter sample. In the case of all remaining countries, the analyses conducted for the whole sample surprisingly made the $95 \%$ confidence intervals much greater than in the case of the shorter series. This leads to much greater uncertainty about labour productivity and its heterogeneity across the analysed countries.

As with convergence parameter $\beta$, we performed a pairwise comparison of estimates of the long-term growth rate of labour productivity across countries. The magnitude of the $p$-value of the test statistics utilised in testing problem (8) are presented in Table 3 (short sample) and Table 4 (the whole dataset). For the majority of the analysed pairs, the short series does not yield any empirical evidence in favour of differences between long-term labour productivity growth rates. We report exceptions, namely in the case of pairs HUN-EST, SVK-EST, SVN-EST, LVA-HUN, LTU-HUN, SVN-LVA, and SVKLVA, where the labour productivity growth rate is statistically different below any reasonable level of significance. A very different picture was obtained for the whole sample (see Table 4). In this case, the inference between the pairwise differences of the labour productivity growth rate is not as model invariant as in the case discussed above. Based onmodel $M_{0}$, no decisive evidence about any heterogeneity of labour productivity growth rate is recorded. In the case of model $M_{1}$, the picture is very diverse. For pairs LTU-CZE, POL-LVA, POL-LTU and SVK-LTU there is no doubt about the statistical significance of the analysed differences. In all remaining cases, the heterogeneity of labour productivity, substantially different when measured by point estimates, is not empirically supported. 
The qualitative analyses of the estimated beta parameters (Figure 2) shows that the differences in the convergence pace decreased over both subperiods.

The period 1992-2007 covers primarily the transformation time, when the structural reforms were introduced. This subperiod also covers the period prior to accession to the EU (the CEE countries joined the EU in the early 2000s). The whole sample covers over 20 years, during which the CEE economies became economically stable countries with similar GDP per capita (Figure 1) as a result of the capital and labour flows between them and the core EU15 countries, EU structural funds and foreign direct investment. These factors make the CEE group relatively homogeneous (see Rapacki, Próchniak, 2009; Strielkowski, Höschle, 2016).

However, in this group, Slovenia and Hungary are slightly different. In 1992, they were characterized by a slightly higher level of GDP per employed person, and during the analysed period (as in Poland) excessive social security expenditures can be noted (Gill. Raiser, 2012).

The estimated long-term growth rates (Figure 3) in the shorter sample show that the highest rates of 5.5-6.5\% are in the Baltic States (LTU, LVA, EST) and the lowest (3\%) can be noticed in SVK, SVN and HUN. In CZE and POL, the estimates are very high (10\% and above) and are statistically insignificant. Analysis based on the entire sample does not significantly change the ranking of countries. The long-term rates are highest in the Baltic States (LTU, EST - 5.5\%) and the lowest rate $(2 \%)$ is in POL.

\subsection{Results obtained for CIS countries}

In this subsection, we present the results of analyses conducted for the set of CIS countries. We performed analogous inference about the heterogeneity of the convergence parameters and function of parameters describing long-term labour productivity growth rate. As with the set of CEE countries, we performed sensitivity analysis with respect to the sample (short series up to 2007, and the whole data set covering the period from 1992 till 2012). Figure 4 presents the point estimates and 95\% confidence intervals of the convergence parameters. The heterogeneity of the convergence pace across the set of analysed countries is supported for the shorter series and for the whole data set. We report very different point estimates of the convergence parameters and a substantially different spread of confidence intervals across the countries. In particular, for KGZ, both datasets and both models $\left(M_{0}\right.$ and $M_{1}$ ) indicate the fastest convergence pace. However, in this case, uncertainty about the parameter describing this effect is the greatest. For a particular country, point estimates of the convergence parameter remain qualitatively unchanged when both the length of the series or the model are changed. This gives empirical evidence in favour of the statement that the analysed set of countries can be characterised by a very diverse convergence pace which seem stable over time, especially during the last decade. 
Tables 9 and 10 present the results of a pairwise comparison of the convergence parameters with respect to both comparative criteria, the length of the dataset (see Table 5 for shorter series and Table 6 for the whole dataset) and the model $\left(M_{0}\right.$ and $\left.M_{1}\right)$. In the case of the 12 countries under analysis, one has to test 66 possible pairs. In the case of the shorter series (Table 5), for 32 pairs of countries there is no data evidence in favour of the heterogeneity of the convergence parameters based on model $M_{0}$ and 23 pairs in $M_{1}$. For the whole time series, this effect seem to strengthen, and in the case of model $M_{0}$ we have 41 pairs, and for model $M_{1}$ there are 27 , with the same convergence parameter statistically. There are also pairs of countries characterised by a very different convergence pace, indicating decisive data support in favour of heterogeneity in the case of both models and both datasets. Among those pairs, one has to mention UZB-GEO and RUS-BLR.

The results of the estimation of the long-term labour productivity rate is presented in Figure 5. The point estimates together with the $95 \%$ confidence intervals are analysed in the case of both models $\left(M_{0}\right.$ and $M_{1}$ ) and both datasets. As with the case of the convergence parameters, statistical inference about the long-term labour productivity rate indicates the existence of substantial heterogeneity among the CIS countries. The point estimates of the underlying function of parameters vary across countries, and are relatively invariant with respect to changes in the model and the sample. There are only two exceptions to this effect, namely BLR and TKM. In those cases, based on the shorter series, the point estimates of the labour productivity growth rate are very different compared to those related to the remaining countries. Additionally, the spread of confidence intervals is huge, making assessment of the productivity growth rate very doubtful within the analysed model framework.

For a pairwise comparison of the long-term growth rates of labour productivity, we conducted a series of tests (8). The magnitude of the resulting $p$-values is presented in Tables 12 and 13. Despite the quite strong variability of the point estimates, statistical uncertainty about the long-term productivity growth rate is great enough to preclude any empirical importance regarding this effect. In the case of the shorter sample, the testing procedure does not yield data in favour of the significance of the differences between the analysed growth rate for predominant number of pairs. This result remains qualitatively unchanged for the longer series, except for AZE, ARM, GEO, KGZ or RUS.

Comparing the obtained convergence estimates in both analysed periods in the CIS countries, it has to be mentioned that the parameters did not change significantly over the years (Table 6). Moreover, taking into account the estimated confidence intervals for the parameters, it seems that diversification has strengthened.

In general, the CIS countries are characterized by higher rates of long-term growth and higher convergence rates than other transition countries. These economies are relatively underdeveloped compared to other transition countries, and structural reforms have not yet been completed in some of them. Additionally, these countries are economically unstable and their economic policies are mainly determined by Russia, which is the main trade partner of most other CIS countries. 
We cannot reject the hypothesis that convergence takes place in particular CIS countries, although the heterogeneity of this group may result in a statistical lack of caching-up for the whole panel (see Vojinović et al., 2010). Taking into account the estimated parameters obtained on the basis of Zellner's estimator and the 1992-2012 period, we can confirm the statistically significant beta convergence in almost all CIS countries. ARM and BLR with yearly GDP per worker growth rate of above $2 \%$, and TJK with stagnant growth, are exceptions. Generally, after the transformation recession ended, many socialist countries started to grow very rapidly, and the hierarchy of countries in that group changed.

Analysis of the long-term productivity growth rate (Figure 5) indicates Azerbaijan (9\% in 1992-2012 and $20 \%$ in 1992-2007) as a leader. Azerbaijan's very rapid economic growth is due to its exports (mainly gas and oil). The lowest long-term rates in the whole period (3-4\%) were obtained by KGZ, RUS, and UKR. The high rates of long-term productivity in the CIS countries compared to CEE can be explained by the relatively high jobless growth in these countries. This growth resulted from the fact that in the early stages of the transformation change, productivity adjustment was significantly higher than employment adjustment. As the transition process proceeds, the growth should lower as a result of the reduced importance of productivity adjustment and the greater significance of employment (Brada, 1989; Onaran, 2008).

\section{Summary}

The main goal of the paper was twofold. Firstly, we estimate the convergence equation in postcommunist countries without the assumption of a constancy of parameters across countries. Secondly, we formally tested the differences between convergence parameters in two settings of a covariance matrix. The variability of parameters and the abovementioned formal testing was obtained by applying the system of Seemingly Unrelated Regression Equations.

The analyses provided in the paper are based on the dataset which covers 8 CEE and 12 CIS countries in 1992-2015. Also, the subperiod 1992-2007 was studied to reveal pre-crisis patterns in the catchingup processes. The point estimates of the convergence parameters in the case of independent country regressions and the SURE model are qualitatively the same in the analysed sample.

The results obtained for the CEE sample that ends in 2007 show strong variability of convergence parameters across the countries, from a value close to -1.5 for Slovenia to a slightly positive value for Poland. In the sample covering the whole period, estimated beta are qualitatively the same, with point estimates localised close to the value of -0.25 , except for Slovenia which his characterised by a convergence pace almost two times faster. The analyses of the estimated beta parameters showed that differences in the convergence pace decreased over both subperiods, and the CEE group has become relatively homogeneous. 
An analogous inference about the heterogeneity of the convergence parameters and the function of the parameters was performed in the case of the CIS countries. The heterogeneity of the convergence pace across the set of analysed countries is supported for two subsamples. Very different point estimates of the convergence parameters, and a substantially different spread of confidence intervals across the countries were reported in case of that group. Generally, we statistically confirmed substantial heterogeneity among the CIS countries and a lack of similar convergence patterns among them. Comparing the obtained convergence estimates in both analysed periods in the CIS countries, we found that the parameters have not changed significantly over the years.

On the basis of the obtained parameters of the convergence equations, we estimated the long-term growth rates of labour productivity in CEE and CIS countries. Again, we analysed the estimates using a shorter sample and the whole dataset. We also compare results obtained in case of model with diagonal and unconstrained matrix of contemporaneous covariances.

The estimated long-term growth rates in CEE countries ranged from 3\% in Slovenia, Slovakia and Hungary to ca. $6 \%$ in the Baltic States. The analysis based on the whole sample did not change the hierarchy of countries, although the estimated growth rates slightly decreased. High rates of long-term productivity in the CIS countries compared to CEE are higher. The lowest rates valued at $3-4 \%$ could be found for Kyrgyzstan, the Russian Federation and Ukraine, and the highest rate (ca. 9\%) can be noticed in the case of Azerbaijan.

It seems that the differences in convergence patterns between the analysed groups can be explained by the level of structural reforms, production structure, institutional and foreign environment, jobless growth and economic freedom.

\section{References}

Abreu, M., De Groot, H. L., \& Florax, R. J. (2005). A Meta-Analysis of $\beta$-Convergence: the Legendary 2\%. Journal of Economic Surveys, 19(3), 389-420.

Arbia, G., Le Gallo, J., \& Piras, G. (2008). Does evidence on regional economic convergence depend on the estimation strategy? Outcomes from analysis of a set of NUTS2 EU regions. Spatial economic analysis, 3(2), 209-224.

Barro, R.J. (1997). Determinants of Economic Growth. A cross-country empirical study, MIT Press.

Barro, R. J., \& Sala-i-Martin, X. (1992). Convergence. Journal of Political Economy, 100(2), 223251.

Barro, R. J., Sala-i-Martin, X., Blanchard, O. J., \& Hall, R. E. (1991). Convergence across states and regions. Brookings papers on economic activity, 107-182.

Barro, R.J., \& Sala-i-Martin, X., (1995) Economic Growth, McGraw-Hill, New York. 
Borsi, M. T., \& Metiu, N. (2015). The evolution of economic convergence in the European Union. Empirical Economics, 48(2), 657-681.

Brada, J C. (1989). Technological Progress and Factor Utilization in Eastern European Economic Growth, Economica, 56 (224), 433-48

Çolak, O. (2015). Convergence revisited: case of EU and Eastern Europe, Regional Science Inquiry, VII (1), 69-81.

Dobson, S., Ramlogan, C., \& Strobl, E. (2006). Why do rates of $\beta$-convergence differ? A metaregression analysis, Scottish Journal of Political Economy 53(2), 153-173.

Forgó, B., \& Jevcák, A. (2015). Economic convergence of central and Eastern European EU member states over the last decade (2004-2014). Directorate General Economic and Financial Affairs (DG ECFIN), European Commission.

Fritsche, U., \& Kuzin, V. (2011). Analysing convergence in Europe using the non-linear single factor model. Empirical Economics, 41, 343-369.

Gill, I., \& Raiser, M. (2012). Golden Growth: Restoring the Lustre of the European Economic Model, World Bank, Washington, DC.

Gligorić, M. (2014). Paths of income convergence between country pairs within Europe. Economic Annals, 59(201), 123-156.

Greta, M., \& Lewandowski, K. (2015). The Impact Of The Global Financial And Economic Crisis Convergence Process In OECD Countries. Comparative Economic Research, 18(1), 81-96.

Halmai, P., \& Vásáry, V. (2012). Convergence crisis: economic crisis and convergence in the European Union. International Economics and Economic Policy, 9(3-4), 297-322.

Hidalgo, C. A., \& Hausmann, R. (2009). The building blocks of economic complexity. Proceedings of the National Academy of Sciences, 106(26), 10570-10575.

Kacprzyk, A. (2016). Economic freedom-growth nexus in European Union countries. Applied Economics Letters, 23(7), 494-497.

Kaitila, V. (2014). Transnational Income Convergence and National Income Disparity: Europe, 1960 2012. Journal of Economic Integration, 29(2), 343-371.

Kim, C. J., \& Piger, J. (2002). Common stochastic trends, common cycles, and asymmetry in economic fluctuations. Journal of Monetary Economics, 49(6), 1189-1211.

Law, S. H., Lim, T. C., \& Ismail, N. W. (2013). Institutions and economic development: A Granger causality analysis of panel data evidence. Economic Systems, 37(4), 610-624. 
Mankiw, N. G, Romer, D., \& D. N. Weil. (1992), A contribution to the empirics of economic growth, The Quarterly Journal of Economics, 107.2 (1992), 407-437.

Marelli, E., \& Signorelli, M. (2015). Convergence, Crisis and Unemployment in Europe: The Need for Innovative Policies. Croatian Economic Survey, 17(2), 5-56.

Onaran, O. (2008). Jobless growth in the central and east European countries: a country-specific panel data analysis of the manufacturing industry. Eastern European Economics, 46(4), 90-115

Özgüzer, G., \& Oğuş-Binatlı, A. (2016). Economic Convergence in the EU: A Complexity Approach. Eastern European Economics, 54(2), 93-108.

Pesaran, M. H. (2007). A pair-wise approach to testing for output and growth convergence. Journal of Econometrics, 138, 312-355.

Phillips, P. C., \& Sul, D. (2007). Transition modeling and econometric convergence tests. Econometrica, 75(6), 1771-1855.

Próchniak M., \& Witkowski B. (2016) On the Use of Panel Stationarity Tests in Convergence Analysis: Empirical Evidence for the EU Countries, Equilibrium, 11(1), 77-96.

Próchniak, M., \& Witkowski, B. (2013). Real $\beta$-Convergence of Transition Countries: Robust Approach. Eastern European Economics, 51(3), 6-26.

Rapacki R., \& Próchniak M. (2009) Real beta and sigma convergence in 27 transition countries, 19902005, Post-Communist Economies, 21(3), 307-326.

Rogut, A., \& Roszkowska, S. (2006) Konwergencja warunkowa w krajach transformacji [Conditional Convergence in Transition Countries], Gospodarka Narodowa, 9, 35-55

Strielkowski, W., \& Höschle, F. (2016) Evidence for economic convergence in the EU: The analysis of past EU enlargements, Technological and Economic Development of Economy, 22(4), 617-630.

Vojinović, B., Oplotnik, Ž. J., \& Próchniak, M. (2010). EU enlargement and real economic convergence. Post-Communist Economies, 22(3), 303-322.

Young, A. T., Higgins, M. J., \& Levy, D. (2013). Heterogeneous convergence. Economics Letters, $120(2), 238-241$.

Zellner, A., (1962) An efficient method of estimating seemingly unrelated regressions and tests for aggregation bias, Journal of the American Statistical Association, 57(298), 348-368. 
Figure 1. The GDP per worker in the CEE and CIS countries (in 1991 and 2015, thousands of \$US, at prices and PPPs of 2005) and the relation of labour productivity between 2015 and 1991 (right scale)

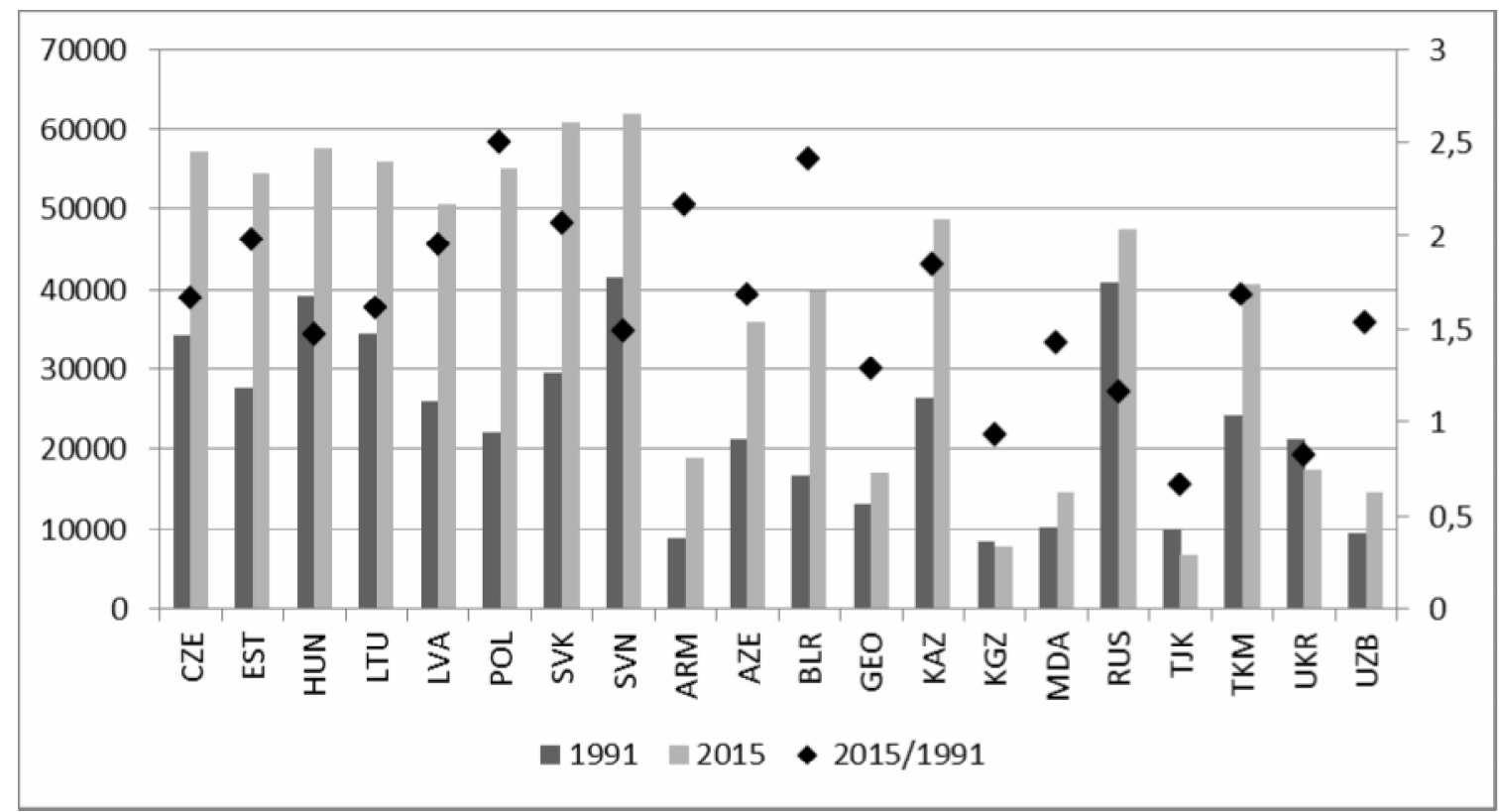


Figure 2. Estimates of convergence parameters in CEE countries together with $95 \%$ confidence intervals.

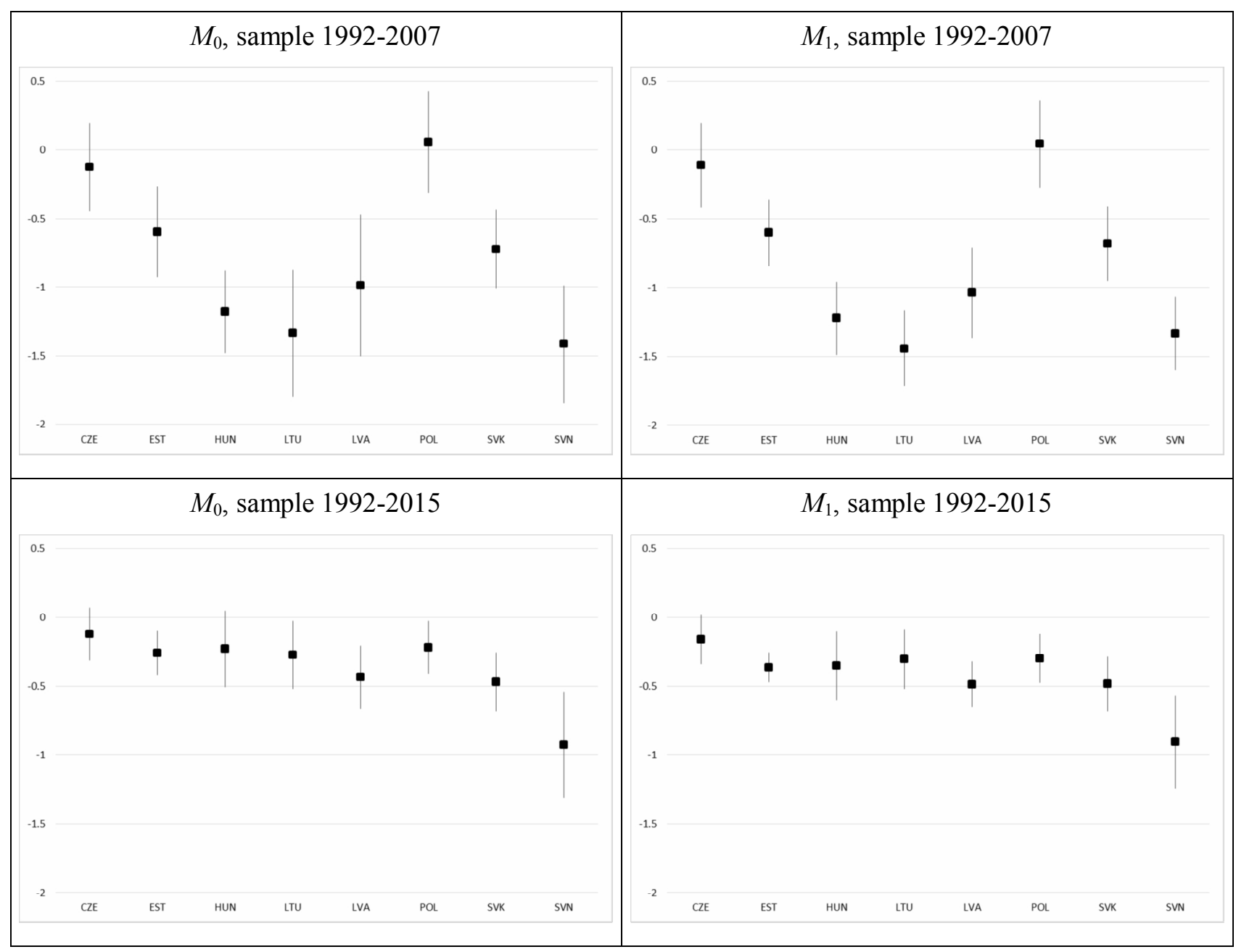


Table 1. Pairwise comparison of estimates of convergence parameter in CEE countries, sample 19922007

\begin{tabular}{|c|c|c|c|c|c|c|c|c|}
\hline \multicolumn{9}{|c|}{ Sample 1992-2007, OLS $\left(M_{0}\right)$} \\
\hline & $\mathrm{CZE}$ & EST & HUN & LVA & LTU & POL & SVK & SVN \\
\hline CZE & & $* *$ & $* * *$ & ** & $* * *$ & no evid. & $* *$ & $* * *$ \\
\hline EST & $* *$ & & $* *$ & no evid. & $* *$ & $* *$ & no evid. & $* * *$ \\
\hline HUN & $* * *$ & $* *$ & & no evid. & no evid. & $* * *$ & $* *$ & no evid. \\
\hline LVA & $* *$ & no evid. & no evid. & & no evid. & $* * *$ & no evid. & no evid. \\
\hline LTU & $* * *$ & $* *$ & no evid. & no evid. & & $* * *$ & $* *$ & no evid. \\
\hline POL & no evid. & $* *$ & $* * *$ & $* * *$ & $* * *$ & & $* * *$ & $* * *$ \\
\hline SVK & $* *$ & no evid. & $* *$ & no evid. & $* *$ & $* * *$ & & $* *$ \\
\hline SVN & $* * *$ & $* * *$ & no evid. & no evid. & no evid. & $* * *$ & $* *$ & \\
\hline \multicolumn{9}{|c|}{ Sample 1992-2007, Zellner $\left(M_{1}\right)$} \\
\hline & CZE & EST & HUN & LVA & LTU & POL & SVK & SVN \\
\hline CZE & & $* *$ & $* * *$ & $* * *$ & $* * *$ & no evid. & $* * *$ & $* * *$ \\
\hline EST & $* *$ & & $* * *$ & $* *$ & $* * *$ & $* * *$ & no evid. & $* * *$ \\
\hline HUN & $* * *$ & $* * *$ & & no evid. & no evid. & $* * *$ & $* * *$ & no evid. \\
\hline LVA & $* * *$ & $* *$ & no evid. & & $*$ & $* * *$ & $*$ & no evid. \\
\hline LTU & $* * *$ & $* * *$ & no evid. & $*$ & & $* * *$ & $* * *$ & no evid. \\
\hline POL & no evid. & $* * *$ & $* * *$ & $* * *$ & $* * *$ & & $* * *$ & $* * *$ \\
\hline SVK & $* * *$ & no evid. & $* * *$ & $*$ & $* * *$ & $* * *$ & & $* * *$ \\
\hline SVN & $* * *$ & $* * *$ & no evid. & no evid. & no evid. & $* * *$ & $* * *$ & \\
\hline
\end{tabular}

$* * * \mathrm{p}<0.01 ; * * \mathrm{p}<0.05 ; * \mathrm{p}<0.1 ;$ no evid. $\mathrm{p}>0.1$ 
Table 2. Pairwise comparison of estimates of convergence parameter in CEE countries, sample 19922015

\begin{tabular}{|c|c|c|c|c|c|c|c|c|}
\hline \multicolumn{9}{|c|}{ Sample 1992-2015, OLS, $\left(M_{0}\right)$} \\
\hline & $\mathrm{CZE}$ & EST & HUN & LVA & LTU & POL & SVK & SVN \\
\hline $\mathrm{CZE}$ & & no evid. & no evid. & $* *$ & no evid. & no evid. & $* *$ & $* * *$ \\
\hline EST & no evid. & & no evid. & no evid. & no evid. & no evid. & no evid. & $* * *$ \\
\hline HUN & no evid. & no evid. & & no evid. & no evid. & no evid. & no evid. & $* * *$ \\
\hline LVA & $* *$ & no evid. & no evid. & & no evid. & no evid. & no evid. & $* *$ \\
\hline LTU & no evid. & no evid. & no evid. & no evid. & & no evid. & no evid. & $* * *$ \\
\hline $\mathrm{POL}$ & no evid. & no evid. & no evid. & no evid. & no evid. & & $*$ & $* * *$ \\
\hline SVK & $* *$ & no evid. & no evid. & no evid. & no evid. & $*$ & & $* *$ \\
\hline SVN & $* * *$ & $* * *$ & $* * *$ & $* *$ & $* * *$ & $* * *$ & $* *$ & \\
\hline \multicolumn{9}{|c|}{ Sample 1992-2015, Zellner, $\left(M_{1}\right)$} \\
\hline & $\mathrm{CZE}$ & EST & HUN & LVA & LTU & $\mathrm{POL}$ & SVK & SVN \\
\hline CZE & & $* *$ & no evid. & $* * *$ & no evid. & no evid. & $* * *$ & $* * *$ \\
\hline EST & $* *$ & & no evid. & no evid. & no evid. & no evid. & no evid. & $* * *$ \\
\hline HUN & no evid. & no evid. & & no evid. & no evid. & no evid. & no evid. & $* *$ \\
\hline LVA & $* * *$ & no evid. & no evid. & & no evid. & no evid. & no evid. & $* *$ \\
\hline LTU & no evid. & no evid. & no evid. & no evid. & & no evid. & no evid. & $* * *$ \\
\hline POL & no evid. & no evid. & no evid. & no evid. & no evid. & & no evid. & $* * *$ \\
\hline SVK & $* * *$ & no evid. & no evid. & no evid. & no evid. & no evid. & & $* *$ \\
\hline SVN & $* * *$ & $* * *$ & $* *$ & $* *$ & $* * *$ & $* * *$ & $* *$ & \\
\hline
\end{tabular}

$* * * \mathrm{p}<0.01 ; * * \mathrm{p}<0.05 ; * \mathrm{p}<0.1$; no evid. $\mathrm{p}>0.1$ 
Figure 3. Estimates of the long-term growth rate of labour productivity in CEE countries in 1992-2015 together with $95 \%$ confidence intervals.

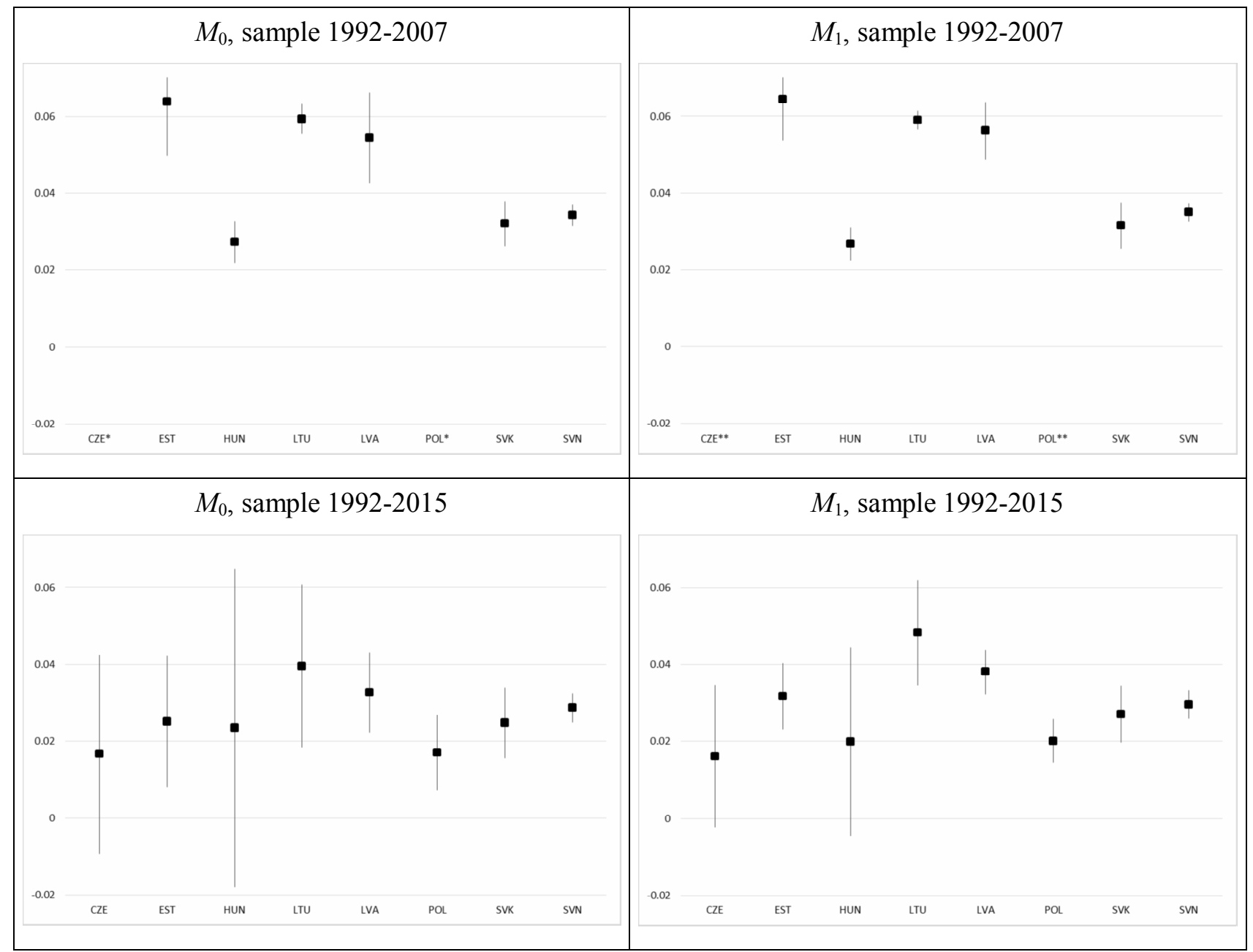

* $95 \%$ confidence interval for CZE is $(-0.07 ; 0.26)$ and for POL is $(-0.53 ; 0.82)$

** $95 \%$ confidence interval for CZE is $(-0.07 ; 0.25)$ and for POL is $(-0.81 ; 1.15)$ 
Table 3. Pairwise comparison of estimates of the long-term growth rate of labour productivity in CEE countries, sample 1992-2007

\begin{tabular}{|c|c|c|c|c|c|c|c|c|}
\hline \multicolumn{9}{|c|}{ Sample 1992-2007, OLS $\left(M_{0}\right)$} \\
\hline & $\mathrm{CZE}$ & EST & HUN & LVA & LTU & POL & SVK & SVN \\
\hline CZE & & no evid. & no evid. & no evid. & no evid. & no evid. & no evid. & no evid. \\
\hline EST & no evid. & & $* * *$ & no evid. & no evid. & no evid. & $* * *$ & $* * *$ \\
\hline HUN & no evid. & $* * *$ & & $* * *$ & $* * *$ & no evid. & no evid. & $* *$ \\
\hline LVA & no evid. & no evid. & $* * *$ & & no evid. & no evid. & $* * *$ & $* * *$ \\
\hline LTU & no evid. & no evid. & $* * *$ & no evid. & & no evid. & $* * *$ & $* * *$ \\
\hline POL & no evid. & no evid. & no evid. & no evid. & no evid. & & no evid. & no evid. \\
\hline SVK & no evid. & $* * *$ & no evid. & $* * *$ & $* * *$ & no evid. & & no evid. \\
\hline SVN & no evid. & $* * *$ & $* *$ & $* * *$ & $* * *$ & no evid. & no evid. & \\
\hline \multicolumn{9}{|c|}{ Sample 1992-2007, Zellner, $\left(M_{1}\right)$} \\
\hline & CZE & EST & HUN & LVA & LTU & POL & SVK & SVN \\
\hline CZE & & no evid. & no evid. & no evid. & no evid. & no evid. & no evid. & no evid. \\
\hline EST & no evid. & & $* * *$ & no evid. & no evid. & no evid. & $* * *$ & $* * *$ \\
\hline HUN & no evid. & $* * *$ & & $* * *$ & $* * *$ & no evid. & no evid. & $* * *$ \\
\hline LVA & no evid. & no evid. & $* * *$ & & no evid. & no evid. & $* * *$ & $* * *$ \\
\hline LTU & no evid. & no evid. & $* * *$ & no evid. & & no evid. & $* * *$ & $* * *$ \\
\hline POL & no evid. & no evid. & no evid. & no evid. & no evid. & & no evid. & no evid. \\
\hline SVK & no evid. & $* * *$ & no evid. & $* * *$ & $* * *$ & no evid. & & no evid. \\
\hline SVN & no evid. & $* * *$ & $* * *$ & $* * *$ & $* * *$ & no evid. & no evid. & \\
\hline
\end{tabular}

$* * * \mathrm{p}<0.01 ; * * \mathrm{p}<0.05 ; * \mathrm{p}<0.1 ;$ no evid. $\mathrm{p}>0.1$ 
Table 4. Pairwise comparison of estimates of the long-term growth rate of labour productivity in CEE countries, sample 1992-2015

\begin{tabular}{|c|c|c|c|c|c|c|c|c|}
\hline \multicolumn{9}{|c|}{ Sample 1992-2015, OLS, $\left(M_{0}\right)$} \\
\hline & $\mathrm{CZE}$ & EST & HUN & LVA & LTU & POL & SVK & SVN \\
\hline CZE & & no evid. & no evid. & no evid. & no evid. & no evid. & no evid. & no evid. \\
\hline EST & no evid. & & no evid. & no evid. & no evid. & no evid. & no evid. & no evid. \\
\hline HUN & no evid. & no evid. & & no evid. & no evid. & no evid. & no evid. & no evid. \\
\hline LVA & no evid. & no evid. & no evid. & & no evid. & $* *$ & no evid. & no evid. \\
\hline LTU & no evid. & no evid. & no evid. & no evid. & & $*$ & no evid. & no evid. \\
\hline POL & no evid. & no evid. & no evid. & $* *$ & $*$ & & no evid. & $* *$ \\
\hline SVK & no evid. & no evid. & no evid. & no evid. & no evid. & no evid. & & no evid. \\
\hline SVN & no evid. & no evid. & no evid. & no evid. & no evid. & $* *$ & no evid. & \\
\hline \multicolumn{9}{|c|}{ Sample 1992-2015, Zellner, $\left(M_{1}\right)$} \\
\hline & CZE & EST & HUN & LVA & LTU & POL & SVK & SVN \\
\hline CZE & & $*$ & no evid. & $* *$ & $* * *$ & no evid. & no evid. & no evid. \\
\hline EST & $*$ & & no evid. & $*$ & $* *$ & $* *$ & no evid. & no evid. \\
\hline HUN & no evid. & no evid. & & no evid. & $* *$ & no evid. & no evid. & no evid. \\
\hline LVA & $* *$ & $*$ & no evid. & & no evid. & $* * *$ & $* *$ & $* *$ \\
\hline LTU & $* * *$ & $* *$ & $* *$ & no evid. & & $* * *$ & $* * *$ & $* *$ \\
\hline $\mathrm{POL}$ & no evid. & $* *$ & no evid. & $* * *$ & $* * *$ & & no evid. & $* * *$ \\
\hline SVK & no evid. & no evid. & no evid. & $* *$ & $* * *$ & no evid. & & no evid. \\
\hline SVN & no evid. & no evid. & no evid. & $* *$ & $* *$ & $* * *$ & no evid. & \\
\hline
\end{tabular}

$* * * \mathrm{p}<0.01 ; * * \mathrm{p}<0.05 ; * \mathrm{p}<0.1$; no evid. $\mathrm{p}>0.1$ 
Figure 4. Estimates of convergence parameters in CIS countries together with $95 \%$ confidence intervals

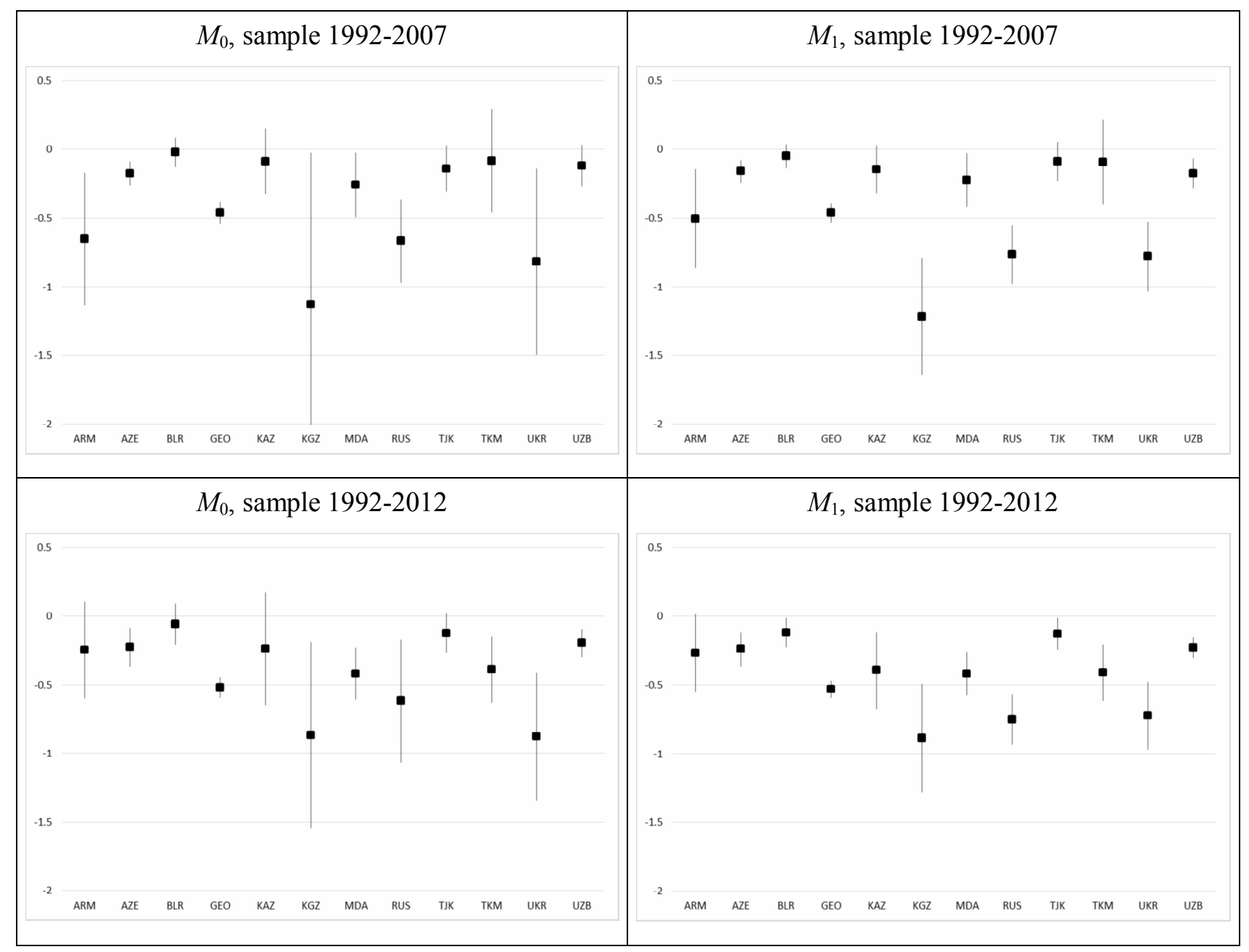


Table 5. Pairwise comparison of estimates of the convergence parameter in CIS countries, sample 1992-2007

\begin{tabular}{|c|c|c|c|c|c|c|c|c|c|c|c|c|}
\hline \multicolumn{13}{|c|}{ Sample 1992-2007, OLS, $\left(M_{0}\right)$} \\
\hline & ARM & AZE & BLR & GEO & KAZ & KGZ & MDA & RUS & TJK & TKM & UKR & UZB \\
\hline ARM & & $*$ & $* *$ & no evid. & $* *$ & no evid. & no evid. & no evid. & $* *$ & $*$ & no evid. & $* *$ \\
\hline AZE & $*$ & & $* *$ & $* * *$ & no evid. & $*$ & no evid. & $* * *$ & no evid. & no evid. & $*$ & no evid. \\
\hline BLR & $* *$ & $* *$ & & $* * *$ & no evid. & $*$ & * & $* * *$ & no evid. & no evid. & $* *$ & no evid. \\
\hline GEO & no evid. & $* * *$ & $* * *$ & & $* * *$ & no evid. & * & no evid. & $* * *$ & * & no evid. & $* * *$ \\
\hline KAZ & $* *$ & no evid. & no evid. & $* * *$ & & $*$ & no evid. & $* * *$ & no evid. & no evid. & $* *$ & no evid. \\
\hline KGZ & no evid. & $*$ & $*$ & no evid. & $*$ & & no evid. & no evid. & $*$ & $*$ & no evid. & $*$ \\
\hline MDA & no evid. & no evid. & $*$ & $*$ & no evid. & no evid. & & $* *$ & no evid. & no evid. & no evid. & no evid. \\
\hline RUS & no evid. & $* * *$ & $* * *$ & no evid. & $* * *$ & no evid. & $* *$ & & $* * *$ & $* *$ & no evid. & $* * *$ \\
\hline TJK & $* *$ & no evid. & no evid. & $* * *$ & no evid. & $*$ & no evid. & $* * *$ & & no evid. & $*$ & no evid. \\
\hline TKM & $*$ & no evid. & no evid. & $*$ & no evid. & $*$ & no evid. & $* *$ & no evid. & & $*$ & no evid. \\
\hline UKR & no evid. & $*$ & $* *$ & no evid. & $* *$ & no evid. & no evid. & no evid. & $*$ & $*$ & & $* *$ \\
\hline $\mathrm{UZB}$ & $* *$ & no evid. & no evid. & $* * *$ & no evid. & $*$ & no evid. & $* * *$ & no evid. & no evid. & $* *$ & \\
\hline \multicolumn{13}{|c|}{ Sample 1992-2007, Zellner, $\left(M_{1}\right)$} \\
\hline & ARM & AZE & BLR & GEO & KAZ & KGZ & MDA & RUS & TJK & TKM & UKR & UZB \\
\hline ARM & & $*$ & $* *$ & no evid. & $*$ & $* *$ & no evid. & no evid. & $* *$ & $*$ & no evid. & $*$ \\
\hline AZE & $*$ & & $*$ & $* * *$ & no evid. & $* * *$ & no evid. & $* * *$ & no evid. & no evid. & $* * *$ & no evid. \\
\hline BLR & $* *$ & $*$ & & $* * *$ & no evid. & $* * *$ & $*$ & $* * *$ & no evid. & no evid. & $* * *$ & $* *$ \\
\hline GEO & no evid. & $* * *$ & $* * *$ & & $* * *$ & $* * *$ & $* *$ & $* *$ & $* * *$ & $* *$ & $* *$ & $* * *$ \\
\hline KAZ & $*$ & no evid. & no evid. & $* * *$ & & $* * *$ & no evid. & $* * *$ & no evid. & no evid. & $* * *$ & no evid. \\
\hline KGZ & $* *$ & $* * *$ & $* * *$ & $* * *$ & $* * *$ & & $* * *$ & $*$ & $* * *$ & $* * *$ & $* *$ & $* * *$ \\
\hline MDA & no evid. & no evid. & $*$ & $* *$ & no evid. & $* * *$ & & $* * *$ & no evid. & no evid. & $* * *$ & no evid. \\
\hline RUS & no evid. & $* * *$ & $* * *$ & $* *$ & $* * *$ & $*$ & $* * *$ & & $* * *$ & $* * *$ & no evid. & $* * *$ \\
\hline TJK & $* *$ & no evid. & no evid. & $* * *$ & no evid. & $* * *$ & no evid. & $* * *$ & & no evid. & $* * *$ & no evid. \\
\hline TKM & $*$ & no evid. & no evid. & $* *$ & no evid. & $* * *$ & no evid. & $* * *$ & no evid. & & $* * *$ & no evid. \\
\hline UKR & no evid. & $* * *$ & $* * *$ & $* *$ & $* * *$ & $* *$ & $* * *$ & no evid. & $* * *$ & $* * *$ & & $* * *$ \\
\hline UZB & $*$ & no evid. & $* *$ & $* * *$ & no evid. & $* * *$ & no evid. & $* * *$ & no evid. & no evid. & $* * *$ & \\
\hline
\end{tabular}


Table 6. Pairwise comparison of convergence parameter in CIS countries, sample 1992-2012

\begin{tabular}{|c|c|c|c|c|c|c|c|c|c|c|c|c|}
\hline \multicolumn{13}{|c|}{ Sample 1992-2012, OLS, $\left(M_{0}\right)$} \\
\hline & ARM & AZE & BLR & GEO & KAZ & KGZ & MDA & RUS & TJK & TKM & UKR & UZB \\
\hline ARM & & no evid. & no evid. & no evid. & no evid. & no evid. & no evid. & no evid. & no evid. & no evid. & $* *$ & no evid. \\
\hline AZE & no evid. & & no evid. & $* * *$ & no evid. & $*$ & no evid. & $*$ & no evid. & no evid. & $* *$ & no evid. \\
\hline BLR & no evid. & no evid. & & $* * *$ & no evid. & $* *$ & $* * *$ & $* *$ & no evid. & $* *$ & $* * *$ & no evid. \\
\hline GEO & no evid. & $* * *$ & $* * *$ & & no evid. & no evid. & no evid. & no evid. & $* * *$ & no evid. & no evid. & $* * *$ \\
\hline KAZ & no evid. & no evid. & no evid. & no evid. & & no evid. & no evid. & no evid. & no evid. & no evid. & $* *$ & no evid. \\
\hline KGZ & no evid. & $*$ & $* *$ & no evid. & no evid. & & no evid. & no evid. & $* *$ & no evid. & no evid. & $*$ \\
\hline MDA & no evid. & no evid. & $* * *$ & no evid. & no evid. & no evid. & & no evid. & $* *$ & no evid. & $*$ & $* *$ \\
\hline RUS & no evid. & $*$ & $* *$ & no evid. & no evid. & no evid. & no evid. & & $* *$ & no evid. & no evid. & $*$ \\
\hline TJK & no evid. & no evid. & no evid. & $* * *$ & no evid. & $* *$ & $* *$ & $* *$ & & $*$ & $* * *$ & no evid. \\
\hline TKM & no evid. & no evid. & $* *$ & no evid. & no evid. & no evid. & no evid. & no evid. & $*$ & & $*$ & no evid. \\
\hline UKR & $* *$ & $* *$ & $* * *$ & no evid. & $* *$ & no evid. & $*$ & no evid. & $* * *$ & $*$ & & $* * *$ \\
\hline UZB & no evid. & no evid. & no evid. & $* * *$ & no evid. & $*$ & $* *$ & $*$ & no evid. & no evid. & $* * *$ & \\
\hline \multicolumn{13}{|c|}{ Sample 1992-2012, Zellner, $\left(M_{1}\right)$} \\
\hline & ARM & AZE & BLR & GEO & KAZ & KGZ & MDA & RUS & TJK & TKM & UKR & UZB \\
\hline ARM & & no evid. & no evid. & $*$ & no evid. & $* *$ & no evid. & $* * *$ & no evid. & no evid. & $* *$ & no evid. \\
\hline AZE & no evid. & & no evid. & $* * *$ & no evid. & $* * *$ & $*$ & $* * *$ & no evid. & no evid. & $* * *$ & no evid. \\
\hline BLR & no evid. & no evid. & & $* * *$ & $* *$ & $* * *$ & $* * *$ & $* * *$ & no evid. & $* *$ & $* * *$ & $*$ \\
\hline GEO & $*$ & $* * *$ & $* * *$ & & no evid. & $*$ & no evid. & $* *$ & $* * *$ & no evid. & no evid. & $* * *$ \\
\hline KAZ & no evid. & no evid. & $* *$ & no evid. & & $* *$ & no evid. & $* *$ & $*$ & no evid. & $* *$ & no evid. \\
\hline KGZ & $* *$ & $* * *$ & $* * *$ & $*$ & $* *$ & & $* *$ & no evid. & $* * *$ & $* *$ & no evid. & $* * *$ \\
\hline MDA & no evid. & $*$ & $* * *$ & no evid. & no evid. & $* *$ & & $* * *$ & $* * *$ & no evid. & $* *$ & $* *$ \\
\hline RUS & $* * *$ & $* * *$ & $* * *$ & $* *$ & $* *$ & no evid. & $* * *$ & & $* * *$ & $* *$ & no evid. & $* * *$ \\
\hline TJK & no evid. & no evid. & no evid. & $* * *$ & $*$ & $* * *$ & $* * *$ & $* * *$ & & $* *$ & $* * *$ & no evid. \\
\hline TKM & no evid. & no evid. & $* *$ & no evid. & no evid. & $* *$ & no evid. & $* *$ & $* *$ & & $*$ & no evid. \\
\hline UKR & $* *$ & $* * *$ & $* * *$ & no evid. & $* *$ & no evid. & $* *$ & no evid. & $* * *$ & $*$ & & $* * *$ \\
\hline UZB & no evid. & no evid. & $*$ & $* * *$ & no evid. & $* * *$ & $* *$ & $* * *$ & no evid. & no evid. & $* * *$ & \\
\hline
\end{tabular}


Figure 5. Estimates of the long-term growth rate of labour productivity in CIS countries in 1992-2012 together with $95 \%$ confidence intervals.

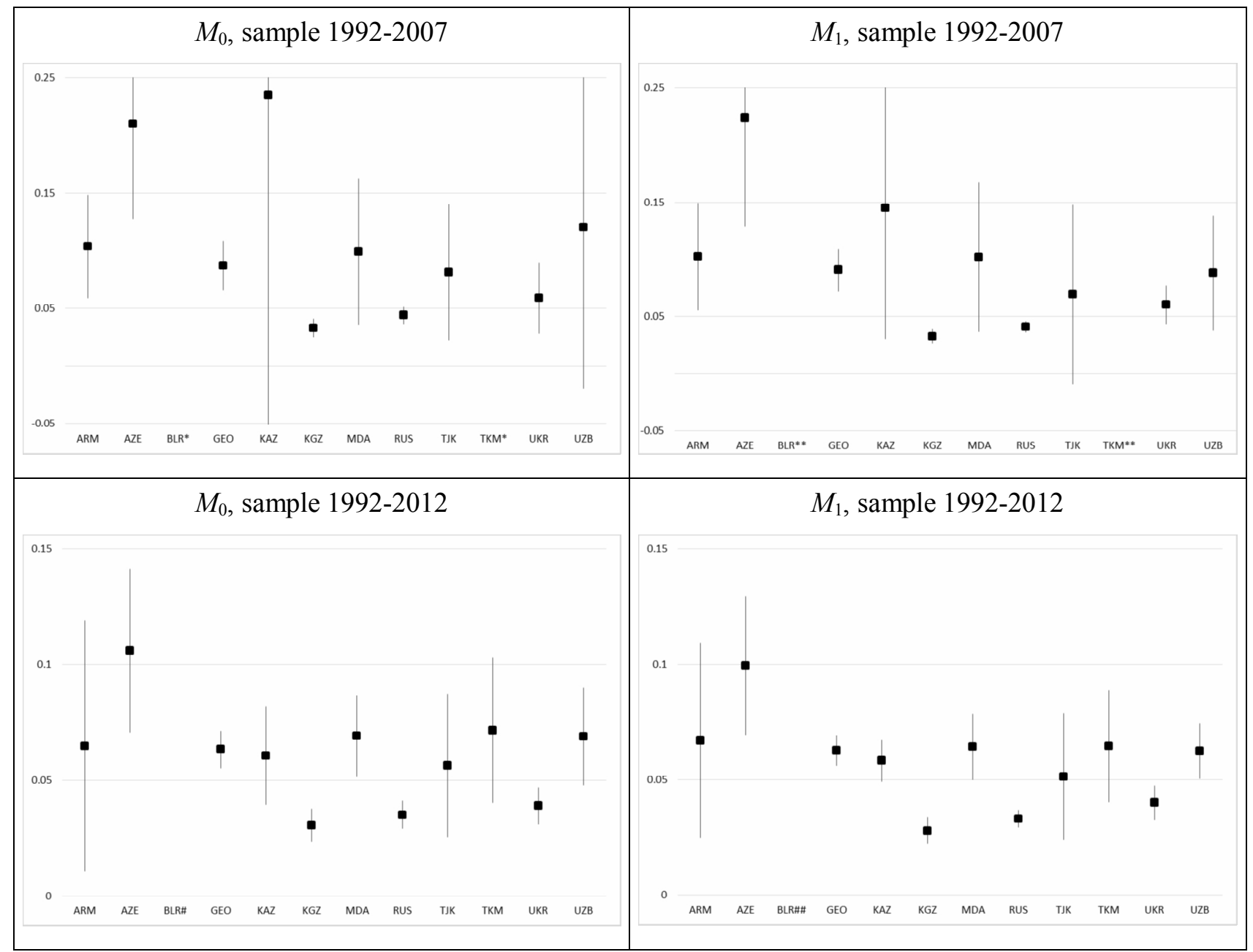

* $95 \%$ confidence interval for BLR is $(-3.13 ; 2.19)$ and for TKM is $(-1.79 ; 2.78)$

** $95 \%$ confidence interval for BLR is $(-0.46 ; 0.21)$ and for TKM is $(-1.31 ; 2.39)$

\# 95\% confidence interval for BLR is $(-0.61 ; 0.38)$

\#\# 95\% confidence interval for BLR is $(-0.09 ; 0.06)$ 
Table 7. Pairwise comparison of estimates of the long-term growth rate of labour productivity in CIS countries, sample 1992-2007

\begin{tabular}{|c|c|c|c|c|c|c|c|c|c|c|c|c|}
\hline \multicolumn{13}{|c|}{ Sample 1992-2007, OLS, $\left(M_{0}\right)$} \\
\hline & ARM & AZE & BLR & GEO & KAZ & KGZ & MDA & RUS & TJK & TKM & UKR & UZB \\
\hline ARM & & $* *$ & no evid. & no evid. & no evid. & $* * *$ & no evid. & $* *$ & no evid. & no evid. & $*$ & no evid. \\
\hline AZE & $* *$ & & no evid. & $* * *$ & no evid. & $* * *$ & ** & $* * *$ & ** & no evid. & $* * *$ & no evid. \\
\hline BLR & no evid. & no evid. & & no evid. & no evid. & no evid. & no evid. & no evid. & no evid. & no evid. & no evid. & no evid. \\
\hline GEO & no evid. & $* * *$ & no evid. & & no evid. & $* * *$ & no evid. & $* * *$ & no evid. & no evid. & no evid. & no evid. \\
\hline KAZ & no evid. & no evid. & no evid. & no evid. & & no evid. & no evid. & no evid. & no evid. & no evid. & no evid. & no evid. \\
\hline KGZ & $* * *$ & $* * *$ & no evid. & $* * *$ & no evid. & & $* *$ & $* *$ & no evid. & no evid. & $*$ & no evid. \\
\hline MDA & no evid. & $* *$ & no evid. & no evid. & no evid. & $* *$ & & $*$ & no evid. & no evid. & no evid. & no evid. \\
\hline RUS & $* *$ & $* * *$ & no evid. & $* * *$ & no evid. & $* *$ & $*$ & & no evid. & no evid. & no evid. & no evid. \\
\hline TJK & no evid. & $* *$ & no evid. & no evid. & no evid. & no evid. & no evid. & no evid. & & no evid. & no evid. & no evid. \\
\hline TKM & no evid. & no evid. & no evid. & no evid. & no evid. & no evid. & no evid. & no evid. & no evid. & & no evid. & no evid. \\
\hline UKR & $*$ & $* * *$ & no evid. & no evid. & no evid. & $*$ & no evid. & no evid. & no evid. & no evid. & & no evid. \\
\hline UZB & no evid. & no evid. & no evid. & no evid. & no evid. & no evid. & no evid. & no evid. & no evid. & no evid. & no evid. & \\
\hline \multicolumn{13}{|c|}{ Sample 1992-2007, Zellner, $\left(M_{1}\right)$} \\
\hline & $\mathrm{ARM}$ & AZE & BLR & GEO & KAZ & KGZ & MDA & RUS & TJK & TKM & UKR & UZB \\
\hline $\mathrm{ARM}$ & & $* *$ & no evid. & no evid. & no evid. & $* * *$ & no evid. & $* *$ & no evid. & no evid. & $*$ & no evid. \\
\hline AZE & $* *$ & & $*$ & $* *$ & no evid. & $* * *$ & $* *$ & $* * *$ & $* *$ & no evid. & $* * *$ & $* *$ \\
\hline BLR & no evid. & $*$ & & no evid. & no evid. & no evid. & no evid. & no evid. & no evid. & no evid. & no evid. & no evid. \\
\hline GEO & no evid. & $* *$ & no evid. & & no evid. & $* * *$ & no evid. & $* * *$ & no evid. & no evid. & $* *$ & no evid. \\
\hline KAZ & no evid. & no evid. & no evid. & no evid. & & $*$ & no evid. & $*$ & no evid. & no evid. & no evid. & no evid. \\
\hline $\mathrm{KGZ}$ & $* * *$ & $* * *$ & no evid. & $* * *$ & $*$ & & $* *$ & $*$ & no evid. & no evid. & $* * *$ & $* *$ \\
\hline MDA & no evid. & $* *$ & no evid. & no evid. & no evid. & $* *$ & & $*$ & no evid. & no evid. & no evid. & no evid. \\
\hline RUS & $* *$ & $* * *$ & no evid. & $* * *$ & $*$ & $*$ & $*$ & & no evid. & no evid. & $* *$ & $*$ \\
\hline TJK & no evid. & $* *$ & no evid. & no evid. & no evid. & no evid. & no evid. & no evid. & & no evid. & no evid. & no evid. \\
\hline TKM & no evid. & no evid. & no evid. & no evid. & no evid. & no evid. & no evid. & no evid. & no evid. & & no evid. & no evid. \\
\hline UKR & $*$ & $* * *$ & no evid. & $* *$ & no evid. & $* * *$ & no evid. & $* *$ & no evid. & no evid. & & no evid. \\
\hline UZB & no evid. & $* *$ & no evid. & no evid. & no evid. & $* *$ & no evid. & $*$ & no evid. & no evid. & no evid. & \\
\hline
\end{tabular}


Table 8. Pairwise comparison of estimates of the long-term growth rate of labour productivity in CIS countries, sample 1992-2012

\begin{tabular}{|c|c|c|c|c|c|c|c|c|c|c|c|c|}
\hline \multicolumn{13}{|c|}{ Sample 1992-2012, OLS, $\left(M_{0}\right)$} \\
\hline & ARM & AZE & BLR & GEO & KAZ & KGZ & MDA & RUS & TJK & TKM & UKR & UZB \\
\hline ARM & & no evid. & no evid. & no evid. & no evid. & no evid. & no evid. & no evid. & no evid. & no evid. & no evid. & no evid. \\
\hline AZE & no evid. & & no evid. & $* *$ & $* *$ & $* * *$ & $*$ & $* * *$ & $* *$ & no evid. & $* * *$ & $*$ \\
\hline BLR & no evid. & no evid. & & no evid. & no evid. & no evid. & no evid. & no evid. & no evid. & no evid. & no evid. & no evid. \\
\hline GEO & no evid. & $* *$ & no evid. & & no evid. & $* * *$ & no evid. & $* * *$ & no evid. & no evid. & $* * *$ & no evid. \\
\hline KAZ & no evid. & $* *$ & no evid. & no evid. & & $* *$ & no evid. & $* *$ & no evid. & no evid. & $*$ & no evid. \\
\hline $\mathrm{KGZ}$ & no evid. & $* * *$ & no evid. & $* * *$ & $* *$ & & $* * *$ & no evid. & no evid. & $* *$ & no evid. & $* * *$ \\
\hline MDA & no evid. & $*$ & no evid. & no evid. & no evid. & $* * *$ & & $* * *$ & no evid. & no evid. & $* * *$ & no evid. \\
\hline RUS & no evid. & $* * *$ & no evid. & $* * *$ & $* *$ & no evid. & $* * *$ & & no evid. & $* *$ & no evid. & $* * *$ \\
\hline TJK & no evid. & $* *$ & no evid. & no evid. & no evid. & no evid. & no evid. & no evid. & & no evid. & no evid. & no evid. \\
\hline TKM & no evid. & no evid. & no evid. & no evid. & no evid. & $* *$ & no evid. & $* *$ & no evid. & & $* *$ & no evid. \\
\hline UKR & no evid. & $* * *$ & no evid. & $* * *$ & $*$ & no evid. & $* * *$ & no evid. & no evid. & $* *$ & & $* *$ \\
\hline UZB & no evid. & $*$ & no evid. & no evid. & no evid. & $* * *$ & no evid. & $* * *$ & no evid. & no evid. & $* *$ & \\
\hline \multicolumn{13}{|c|}{ Sample 1992-2012, Zellner, $\left(M_{1}\right)$} \\
\hline & ARM & AZE & BLR & GEO & KAZ & KGZ & MDA & RUS & TJK & TKM & UKR & UZB \\
\hline ARM & & no evid. & $*$ & no evid. & no evid. & $*$ & no evid. & no evid. & no evid. & no evid. & no evid. & no evid. \\
\hline AZE & no evid. & & $* * *$ & $* *$ & $* * *$ & $* * *$ & $* *$ & $* * *$ & $* *$ & $*$ & $* * *$ & $* *$ \\
\hline BLR & $*$ & $* * *$ & & $* *$ & $*$ & no evid. & $* *$ & no evid. & $*$ & $* *$ & no evid. & $* *$ \\
\hline GEO & no evid. & $* *$ & $* *$ & & no evid. & $* * *$ & no evid. & $* * *$ & no evid. & no evid. & $* * *$ & no evid. \\
\hline KAZ & no evid. & $* * *$ & $*$ & no evid. & & $* * *$ & no evid. & $* * *$ & no evid. & no evid. & $* * *$ & no evid. \\
\hline KGZ & $*$ & $* * *$ & no evid. & $* * *$ & $* * *$ & & $* * *$ & no evid. & $*$ & $* * *$ & $* * *$ & $* * *$ \\
\hline MDA & no evid. & $* *$ & $* *$ & no evid. & no evid. & $* * *$ & & $* * *$ & no evid. & no evid. & $* * *$ & no evid. \\
\hline RUS & no evid. & $* * *$ & no evid. & $* * *$ & $* * *$ & no evid. & $* * *$ & & no evid. & $* *$ & $*$ & $* * *$ \\
\hline TJK & no evid. & $* *$ & $*$ & no evid. & no evid. & $*$ & no evid. & no evid. & & no evid. & no evid. & no evid. \\
\hline TKM & no evid. & $*$ & $* *$ & no evid. & no evid. & $* * *$ & no evid. & $* *$ & no evid. & & $*$ & no evid. \\
\hline UKR & no evid. & $* * *$ & no evid. & $* * *$ & $* * *$ & $* * *$ & $* * *$ & $*$ & no evid. & $*$ & & $* * *$ \\
\hline UZB & no evid. & $* *$ & $* *$ & no evid. & no evid. & $* * *$ & no evid. & $* * *$ & no evid. & no evid. & $* * *$ & \\
\hline
\end{tabular}

